\title{
Właściwości aluminiowych złączy lutowanych lutami na osnowie cynku
}

\author{
The properties of aluminum joints \\ soldered with zinc base solder
}

\section{Streszczenie}

Lutowanie aluminium oraz jego stopów lutami na osnowie cynku o stosunkowo niskiej temperaturze topnienia $\left(382-450{ }^{\circ} \mathrm{C}\right)$ ma coraz większe znaczenie $z$ uwagi na możliwość lutowania elementów o małych grubościach. Jest ono stosowane w budowie urządzeń chłodniczych, klimatyzacyjnych oraz kolektorów słonecznych. W artykule przedstawiono właściwości złączy kielichowych rur lutowanych przy użyciu lutów na osnowie cynku z zawartością 2, 4 i $22 \%$ wag. Al oraz topnika TLA 4 zawierającego fluoroglinian cezu. Przedstawiono wyniki badań wizualnych, metalograficznych oraz ze statycznej próby ścinania połączeń lutowanych płomieniowo. Przedstawiono również dla porównania wyniki prób lutowania indukcyjnego złączy rurowych lutem ZnAl4.

Słowa kluczowe: lutowanie; aluminium; luty cynkowe; własności połączeń

\section{Abstract}

Soldering of aluminum and its alloys with the use of zinc base solders with a relatively low melting point $\left(382-450{ }^{\circ} \mathrm{C}\right)$ is very important where there is the small thickness of soldered components. It is increasingly being used in the construction of refrigeration, air conditioning and solar panels. This paper presents the properties of joints of tubes soldered using the zinc based solders that contain 2, 4 and $22 \mathrm{wt} . \%$. Al and flux TLA 4 containing cesium fluoroaluminate. The paper presents the results of visual tests, metallographic tests as well as a shear strength tests soldered joints heated by flame. Also presented the results of tests of pipes joints soldered with a ZnAl4 solder using induction heating.

Keywords: soldering; aluminum; zinc solders; properties joints

\section{Wstęp}

Zagadnienie wpływu lutu na osnowie cynku na jakość aluminiowych złączy nie jest wyczerpująco opisane w literaturze. Materiał ten i technika spajania, będąca przedmiotem rozważań w niniejszym artykule, są obecnie stosowane do produkcji wielu wyrobów w różnych obszarach przemysłu. Powodem tak licznych zastosowań są szczególnie osobliwe właściwości aluminium i jego stopów oraz w wielu przypadkach niemożność zastosowania złączy spawanych ze względu na grubości ścianek oraz specyfikę wyrobów. Lutowanie jako technika spajania jest stosowana powszechnie do łączenia komponentów wymienników ciepła, elementów radarów, sprzętu AGD i innych aluminiowych produktów.

Jednym z kierunków zmian zachodzących w wytwarzaniu wyrobów jest poprawa jakości lutowanych połączeń aluminiowych poprzez dobór lutu gwarantującego lepsze ich właściwości. Można to osiągnąć przez zmianę składu chemicznego spoiwa lub postać lutu. Luty na osnowie cynku, o niedużym procentowym (wagowym) udziale aluminium, są już od pewnego czasu używane jako spoiwo do wykonywania połączeń sytemu parownika w chłodziarkach lub suszarkach. Stosunkowo niedawno znalazły zastosowanie luty na bazie cynku o zawartości $22 \%$ wag. Al o temperaturze topnienia $426 \div 485{ }^{\circ} \mathrm{C}$. Stosowanie tego lutu jest ściśle związane z wprowadzeniem na rynek niekorozyjnego topnika zawierającego fluoroglinian cezu. Temperatura aktywacji tego topnika wynosząca $420 \div 480{ }^{\circ} \mathrm{C}$ jest doskonale dopasowana do temperatury topnienia lutów na bazie cynku z większą zawartością aluminium, np. lutu rodzaju ZnAl22.

Lutami na osnowie cynku można lutować części z aluminium i jego stopów płomieniowo lub indukcyjnie.

\section{Przykłady zastosowania aluminium w wyrobach lutowanych}

Aluminium i jego stopy są szeroko stosowane, jako materiał konstrukcyjny, z którego powstaje szereg wyrobów

Prof. dr hab. inż. Andrzej Ambroziak, dr inż. Piotr Białucki, dr inż. Wiesław Derlukiewicz, dr inż. Artur Lange - Politechnika Wrocławska.

Autor korespondencyjny/Corresponding author: wieslaw.derlukiewicz@pwr.edu.pl 
w różnych gałęziach przemysłu. Głównie są to przede wszystkim takie obszary jak: konstrukcje budowlane, transport, elektronika, elektrotechnika, urządzenia i maszyny oraz opakowania [1]. Przykładowe obszary zastosowań aluminium i jego stopów w wyrobach lutowanych przedstawiono na rysunku 1.

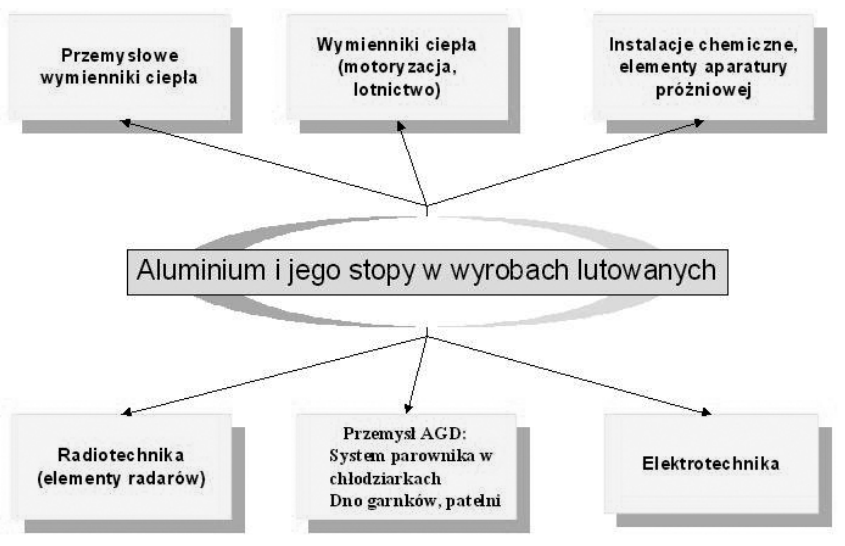

Rys. 1. Obszary zastosowania lutowanych wyrobów aluminiowych $[2,3]$ Fig. 1. The fields of application of soldered aluminum products $[2,3]$

\section{Charakterystyka lutowności aluminium}

Lutowanie nie jest wyjątkowo kłopotliwym procesem spajania elementów z aluminium i jego stopów. Niemniej jednak istnieje kilka czynników, które należy wziąć pod uwagę, aby móc wykonać lutowane złącza o jak najlepszej jakości. Lutownością nazywamy zdolność materiałów łączonych oraz spoiwa do wytworzenia złącza lutowanego, spełniającego ustalone wymagania. Zależy ona od $[2,4]$ :

- rodzaju rodzimego materiału,

- konstrukcji złączy lutowanych,

- parametrów i warunków lutowania,

- przygotowania powierzchni

- metody lutowania,

- rodzaju materiału dodatkowego - spoiwa oraz topnika.

W przypadku aluminium i jego stopów, natrafiamy na kilka przyczyn pogarszających lutowność tego materiału w kontekście stosowanych obecnie materiałów dodatkowych, metod i technik lutowania. Należą do nich następują-

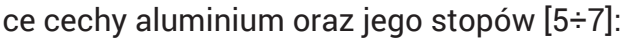

- duże powinowactwo chemiczne do tlenu - przy zetknięciu z powietrzem aluminium pokrywa się niezwilżaną przez luty, trudnotopliwą $\left(2040{ }^{\circ} \mathrm{C}\right)$, trwałą chemicznie (energia tworzenia $1116,3 \mathrm{~kJ} / \mathrm{mol} \mathrm{O}_{2}$ ) i szczelną powłoką tlenku $\mathrm{Al}_{2} \mathrm{O}_{3}$ o gęstości $3,9 \mathrm{~g} / \mathrm{cm}^{3}$ (większej od czystego aluminium $2,7 \mathrm{~g} / \mathrm{cm}^{3}$ );

- stosunkowo niska temperatura topnienia (aluminium $658^{\circ} \mathrm{C}$, stopy aluminium $570-640^{\circ} \mathrm{C}$ );
- niewielkie właściwości mechaniczne, zwłaszcza w temperaturach odpowiadających temperaturom lutowania twardego, tj. powyżej $500^{\circ} \mathrm{C}$;

- duży współczynnik rozszerzalności liniowej Al - 23,6•10-6 1/K, 2-krotnie większy w porównaniu ze stalami niestopowymi;

- brak barw nalotowych przy podgrzewaniu, ułatwiających ocenę temperatury lutowania, tak jak przy nagrzewaniu stali czy też miedzi i jej stopów;

- wysoka cieplna przewodność aluminium: $247 \mathrm{~W} / \mathrm{m} \cdot \mathrm{K}$, większa od żelaza o $310 \%(\mathrm{Fe}-80 \mathrm{~W} / \mathrm{m} \cdot \mathrm{K})$;

- klasyfikacja aluminium (ze względu na potencjał elektrochemiczny), jako metalu mniej szlachetnego w stosunku do większości metali (potencjalnych spoiw), co może skutkować korozją elektrochemiczną złącza.

Spośród wymienionych cech najbardziej utrudniającą lutowanie jest jego wysoce ujemna energia tworzenia tlenków.

\section{Materiały lutownicze stosowane w badaniach}

Temperatura topnienia zastosowanych lutów mieści się $\mathrm{w}$ przedziale $382-485{ }^{\circ} \mathrm{C}$. Najniższą temperaturę topnienia i najwęższy zakres krystalizacji ma lut ZnAl4 (382-387 $\left.{ }^{\circ} \mathrm{C}\right)$, którego skład chemiczny zbliżony jest do składu eutektycznego ( $5 \% \mathrm{Al})$. W próbach lutowania zastosowano luty ZnAl2 i ZnAl22 w postaci drutów rdzeniowych o średnicy $1,6 \mathrm{~mm}$ z niekorozyjnym topnikiem. Lut ZnAl4 stosowano w postaci litych prętów o średnicy $2 \mathrm{~mm}$ z topnikiem INSTAL FLUX TLA 4 [8] o temperaturze aktywności $420-480{ }^{\circ} \mathrm{C} w$ postaci pasty oraz jako pręty otulone z zawartością topnika $25 \%$.

\section{Próby lutowania złączy}

Do wykonania połączeń lutowanych użyto rur o średnicy 12 i 18 mm i grubości ścianki 1 mm w gat. EN AW 6063 (EN AW-AlMg0,7Si) [1]. Połączenia kielichowe lutowano stosując nagrzewanie płomieniem propanowo - tlenowym (rys. 2a) oraz indukcyjnie za pomocą urządzenia firmy CEIA Włochy (rys. 2b).

W celu sprawdzenia wypełnienia szczeliny lutowniczej lutem, w różnych przyjętych kombinacjach lut-topnik, przyjęto w złączach zakładkę o długość $16 \mathrm{~mm}$. Złącze w obu metodach lutowania ustawiano w pozycji pionowej dozując lut ręcznie na zewnątrz szczeliny.

Wykonane złącza zostały poddane badaniom wizualnym oraz metalograficznym (lutowane płomieniowo $i$ indukcyjnie), a także statycznej próbie ścinania (lutowane płomieniowo).

Tablica I. Skład chemiczny lutów na bazie cynku oraz ich temperatura topnienia $[8,9]$

Table I. The chemical composition of the zinc-based solder and the melting point $[8,9]$

\begin{tabular}{|c|c|c|c|c|c|}
\hline \multirow{2}{*}{$\begin{array}{l}\text { Oznaczenie } \\
\text { skrótowe lutu }\end{array}$} & \multirow{2}{*}{$\begin{array}{l}\text { Oznaczenie } \\
\text { spoiwa wg } \\
\text { PN-EN ISO } \\
3677: 2001\end{array}$} & \multicolumn{2}{|c|}{$\begin{array}{c}\text { Skład chemiczny } \\
\text { [\%wag.] }\end{array}$} & \multicolumn{2}{|c|}{$\begin{array}{c}\text { Zakres temperatury } \\
\left.\text { topnienia lutu [ }{ }^{\circ} \mathrm{C}\right]\end{array}$} \\
\hline & & $\mathrm{Zn}$ & Al & Solidus & Likwidus \\
\hline ZnAl2 & S - Zn98Al2 & 98 & 2 & 382 & 407 \\
\hline ZnAl4 & S - Zn98Al4 & 96 & 4 & 382 & 387 \\
\hline ZnAl22 & S - Zn78Al22 & 78 & 22 & 426 & 485 \\
\hline
\end{tabular}




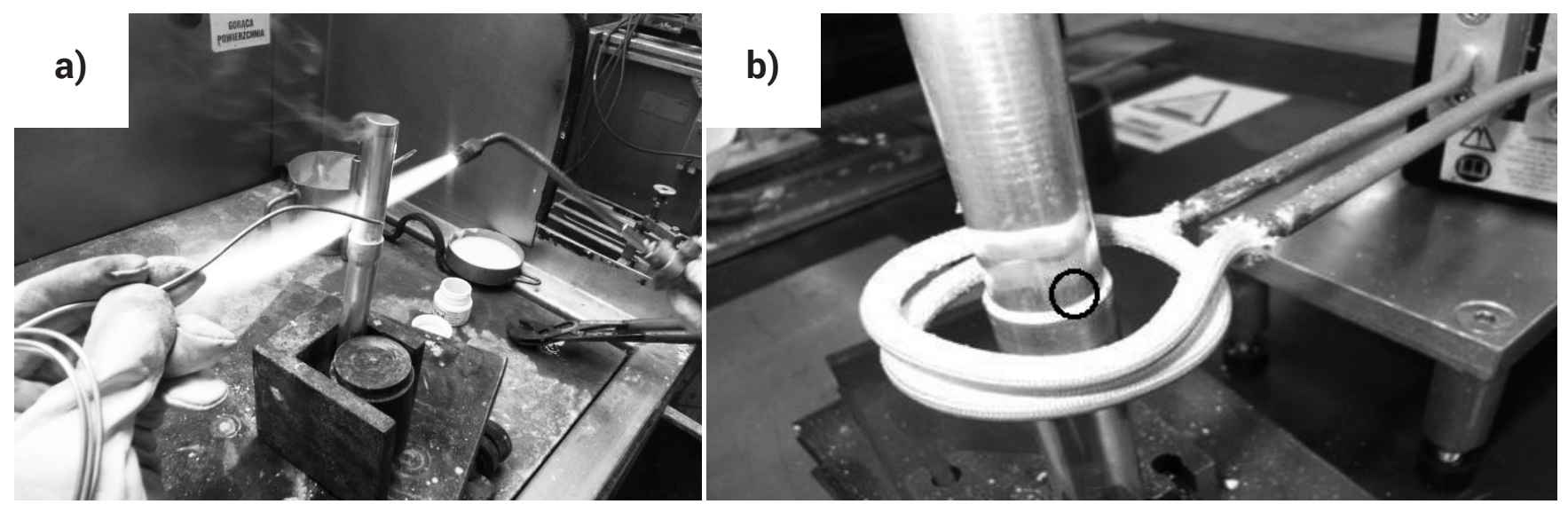

Rys. 2. Stanowiska do lutowania złączy aluminiowych lutami na osnowie cynku: a) płomieniowo, b) indukcyjnie Fig. 2. The positions for soldering of aluminum joints using zinc based solders: a) by the flame, b) by induction

\section{Badania wizualne i metalograficzne połączeń}

Wykonane lutami ZnAl (miękko) złącza oceniono w oparciu o normy lutowania twardego, z uwagi na brak odpowiednich norm dla lutowania miękkiego. Badania wizualne przeprowadzono zgodnie z PN-EN 12799:2003, a badania metalograficzne wg PN-EN 12797:2002. Niezgodności w złączach lutowanych klasyfikowano zgodnie z PN-EN ISO 18279 (Lutowanie twarde - Niezgodności w połączeniach lutowanych).

Ocenę wizualną złączy przeprowadzono nieuzbrojonym okiem oraz przy zastosowaniu lupy o powiększeniu 5x. Przykładowy widok złączy lutowanych płomieniowo przy użyciu lutu ZnAl4, w postaci pręta litego i topnika TLA 4 oraz lutu otulonego ZnAl4Fc, przedstawiono na rysunku 3, a lutowanych indukcyjnie na rysunku 4.
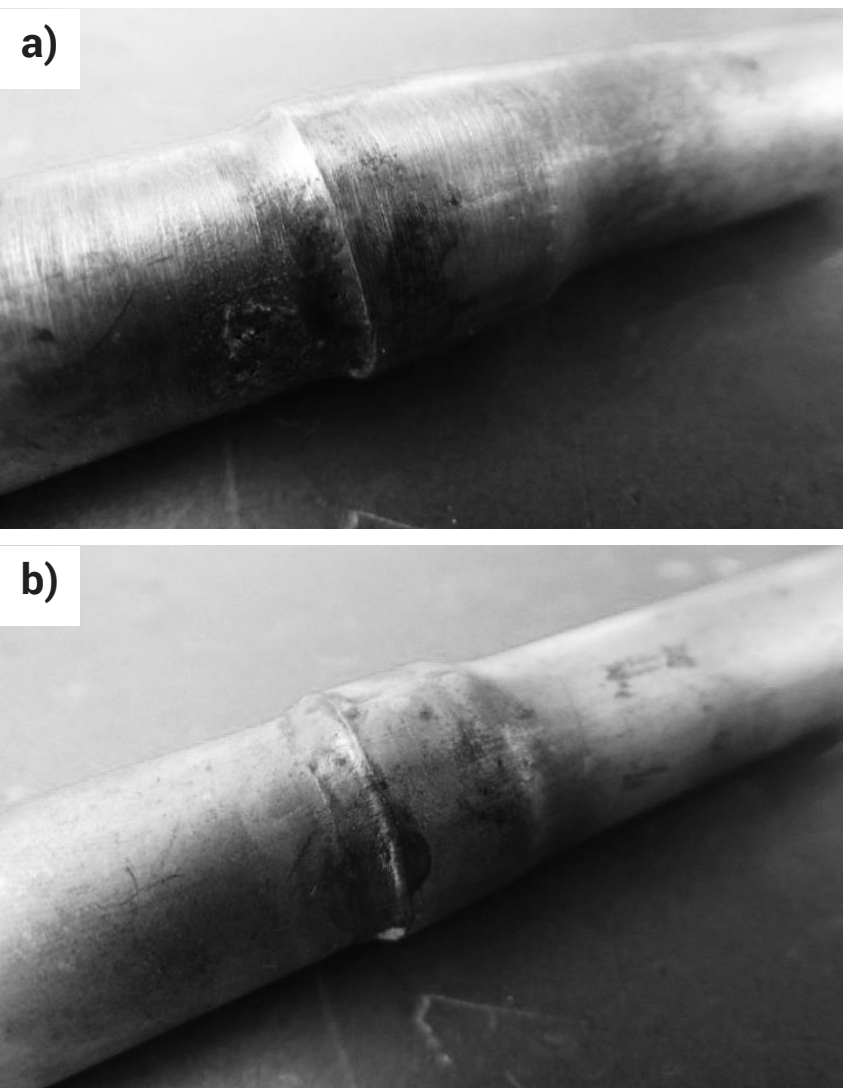

Rys. 3. Złącza lutowane płomieniowo; a) lutem ZnAl4 z topnikiem TLA4, b) lutem ZnAl4Fc otulonym

Fig. 3. Joints soldered by flame method; a) ZnAl4 solder with flux TLA4, b) ZnAl4Fc coated solder
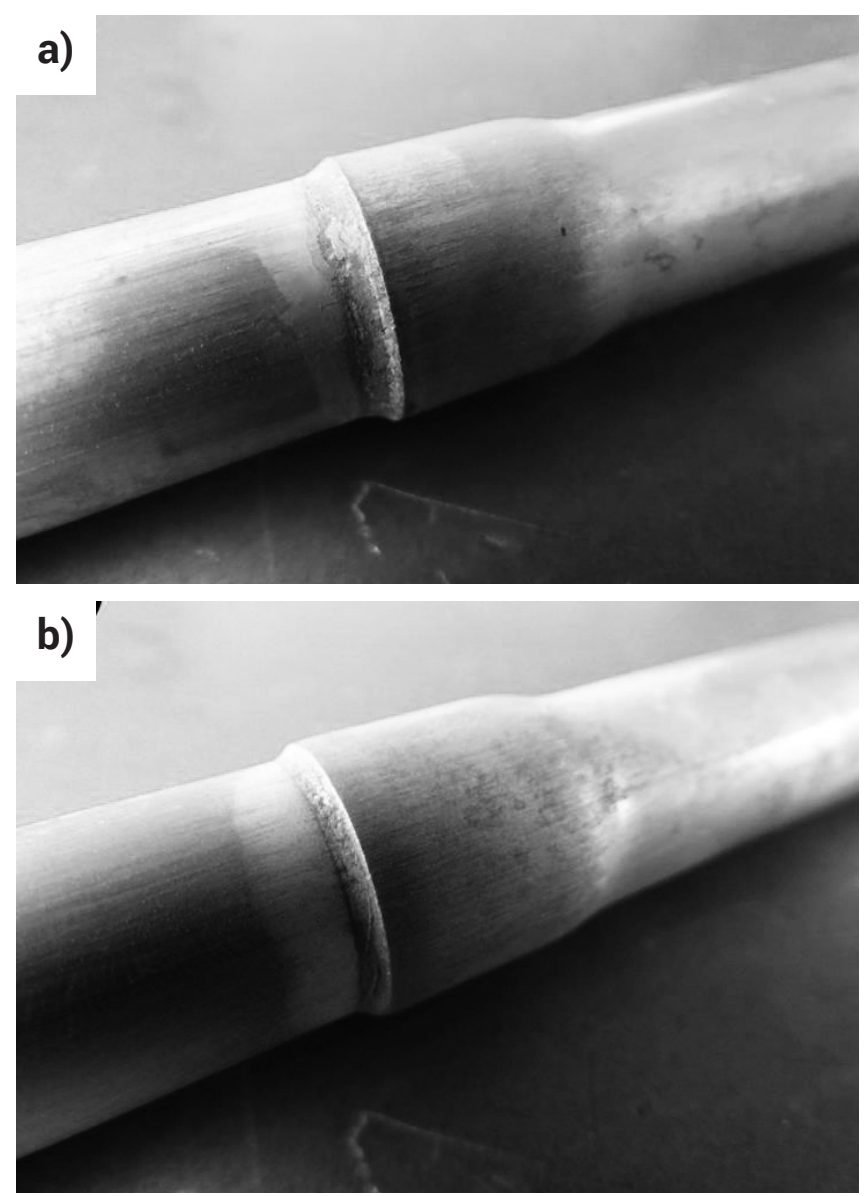

Rys. 4. Złącza lutowane indukcyjnie; a) lutem ZnAl4 z topnikiem TLA4, b) lutem ZnAl4Fc otulonym

Fig. 4. Joints soldered by induction method; a) ZnAl4 solder with flux TLA4, b) ZnAl4Fc coated solder

Znacznie mniej niezgodności wykryto w złączach lutowanych indukcyjnie, były to głównie: nieregularna wypływka pachwinowa lutowiny (5GAAA), chropowatość powierzchni lutowiny (5HAAA) oraz nadmiar lutu (6BAAA).

Uznano, że estetyka złączy lutowanych indukcyjnie przy użyciu lutu ZnAl4 jest dużo lepsza od lutowanych płomieniowo.

Przykładową makrostrukturę losowo wybranych złączy lutowanych płomieniowo i indukcyjnie przy użyciu lutu ZnAl4 przedstawiono na rysunkach 5 i 6 . Więcej niezgodności wewnętrznych takich jak: niecałkowite wypełnienie szczeliny lutowniczej 4JAAA, niedolutowania 4CAAC, pęcherze gazowe 2BGHA, wtrącenia topnikowe 3CAAA czy też nadmierne przereagowanie spoiwa $z$ materiałem lutowanym, stwierdzono w złączach lutowanych płomieniowo. 
a)

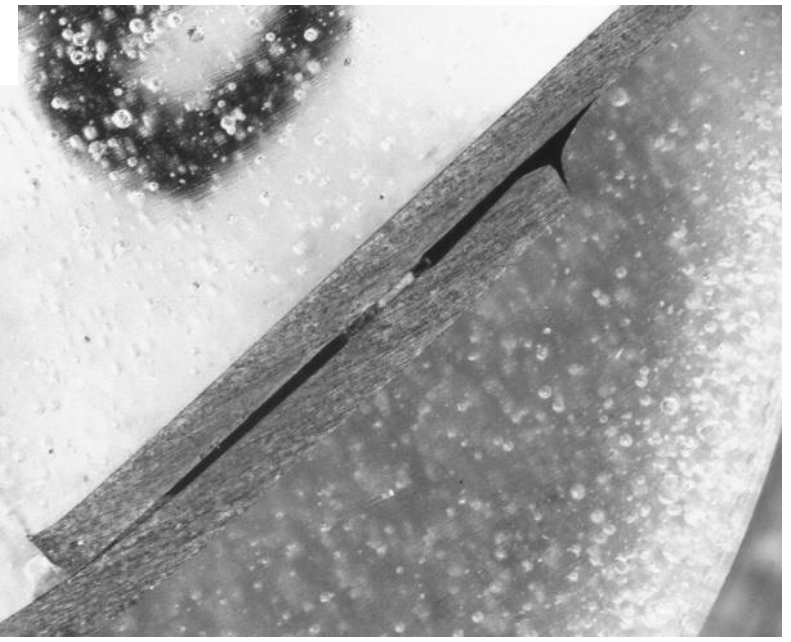

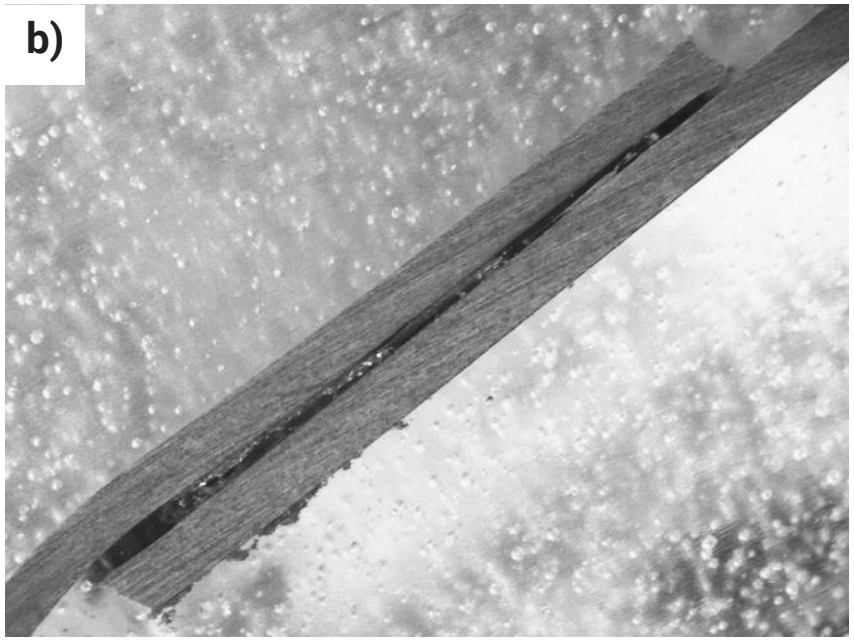

b)

Rys. 5. Makrostruktura złączy lutowanych płomieniowo: a) lutem ZnAl4 z topnikiem TLA4, b) lutem ZnAl4Fc otulonym

Fig. 5. Macrostructure of soldered joints from aluminium by flame method: a) ZnAl4 solder with flux TLA4, b) ZnAl4Fc coated solder
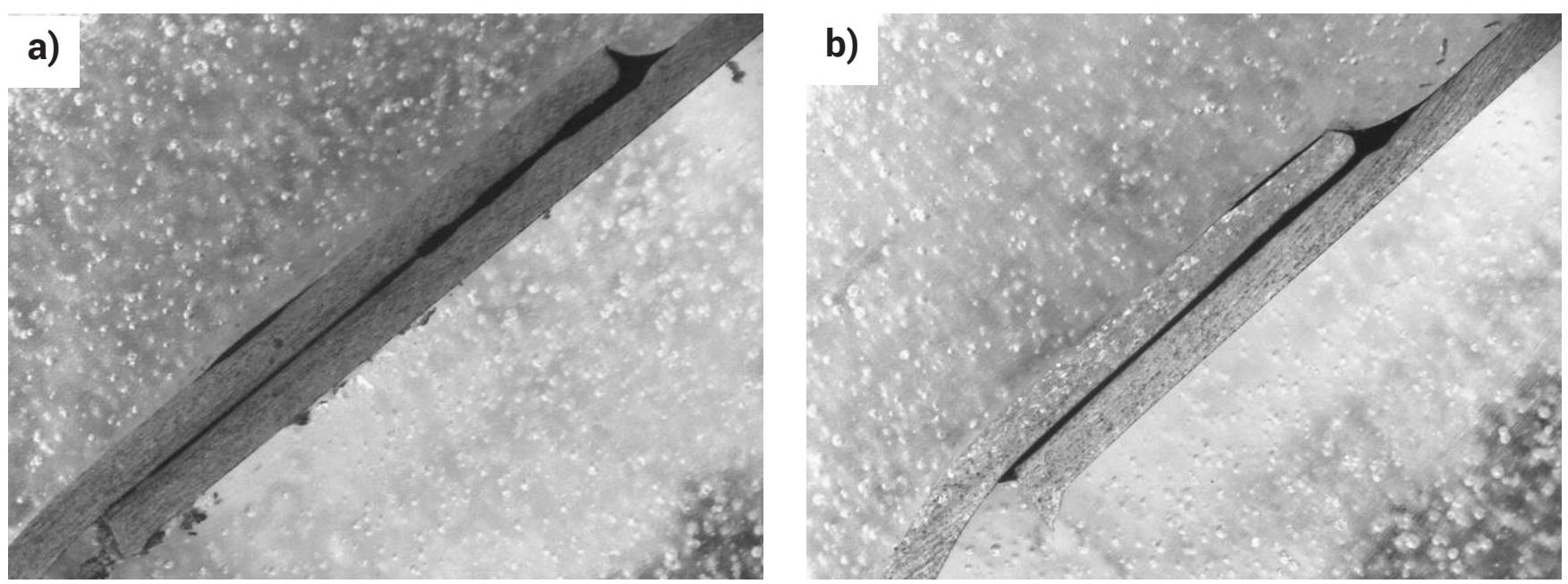

Rys. 6. Makrostruktura złączy lutowanych indukcyjnie: a) lutem ZnAl4 z topnikiem TLA4, b) lutem ZnAl4Fc otulonym

Fig. 6. Macrostructure of soldered joints from aluminium by induction method: a) ZnAl4 solder with flux TLA4, b) ZnAl4Fc coated solder

\section{Statyczna próba ścinania połączeń lutowanych}

Połączenia kielichowe rurowe lutowane płomieniowo poddano statycznej próbie ścinania na maszynie wytrzymałościowej firmy Matest (rys. 7), o zakresie obciążenia do 10 kN.

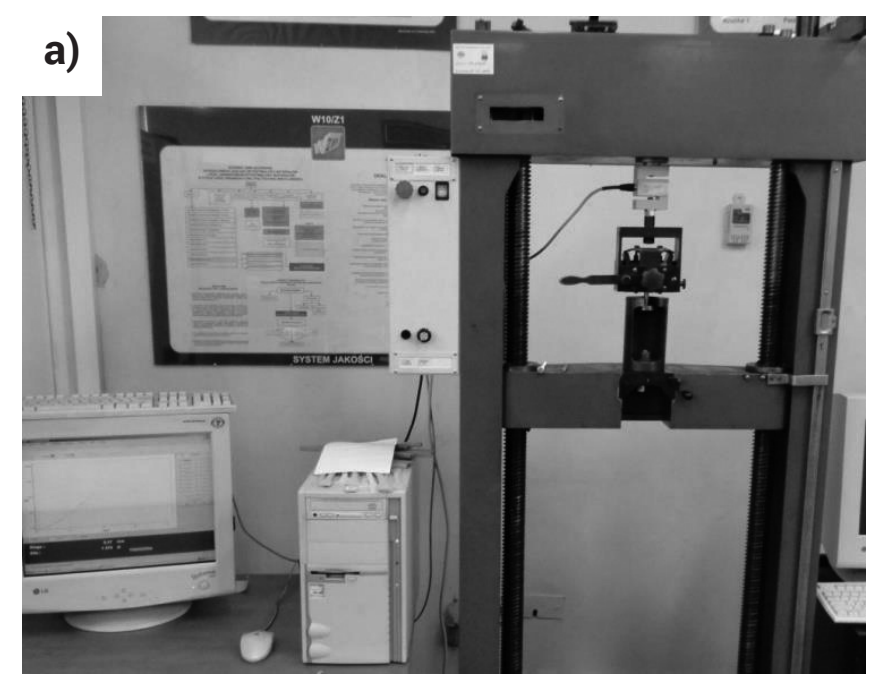

Prędkość przesuwu belki poprzecznej maszyny wynosiła $2 \mathrm{~mm} / \mathrm{min}$. Próby wytrzymałościowe przeprowadzono w pomieszczeniu, w którym temperatura otoczenia wynosiła $27,4{ }^{\circ} \mathrm{C}$, a wilgotność powietrza 49,8\%. Próbkę poddawaną badaniom wytrzymałościowym mocowano w uchwycie samocentrującym (rys. 7b), stosując trzpień wkładany do rurki, aby nie zgnieść jej podczas mocowania.

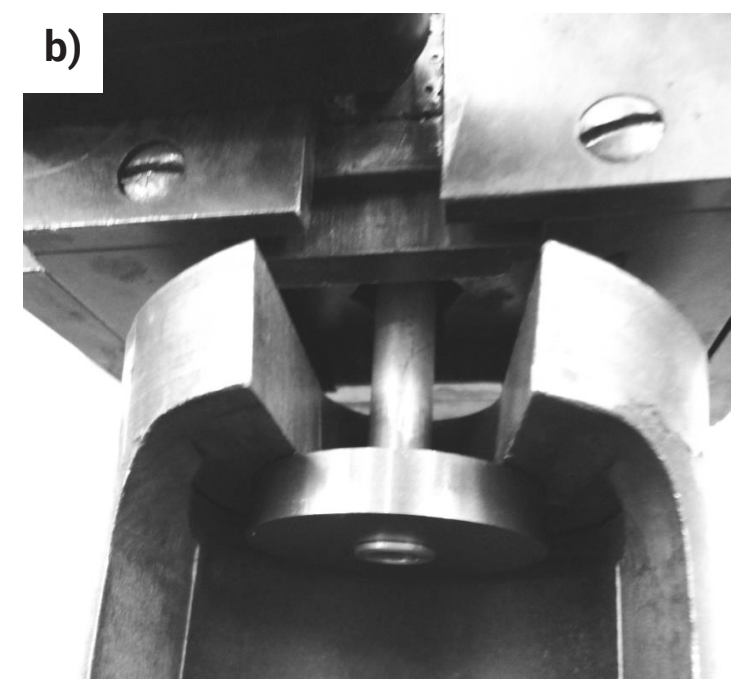

Rys. 7. Stanowisko do badań wytrzymałościowych: a) maszyna wytrzymałościowa, b) próbka w uchwycie samocentrującym Fig. 7. Equipment for the testing the strength of soldered joints: a) testing machine, b) the sample holder self-centering 
Początkowo założono długość zakładki 2 mm, spodziewając się dużo mniejszej wytrzymałości na ścinanie badanych złączy, od podanej przez jednego z producentów lutów (ok. $110 \mathrm{MPa}$ [10]). Po przeprowadzeniu statycznej próby ścinania na dwóch próbkach, które uległy zniszczeniu w ma-
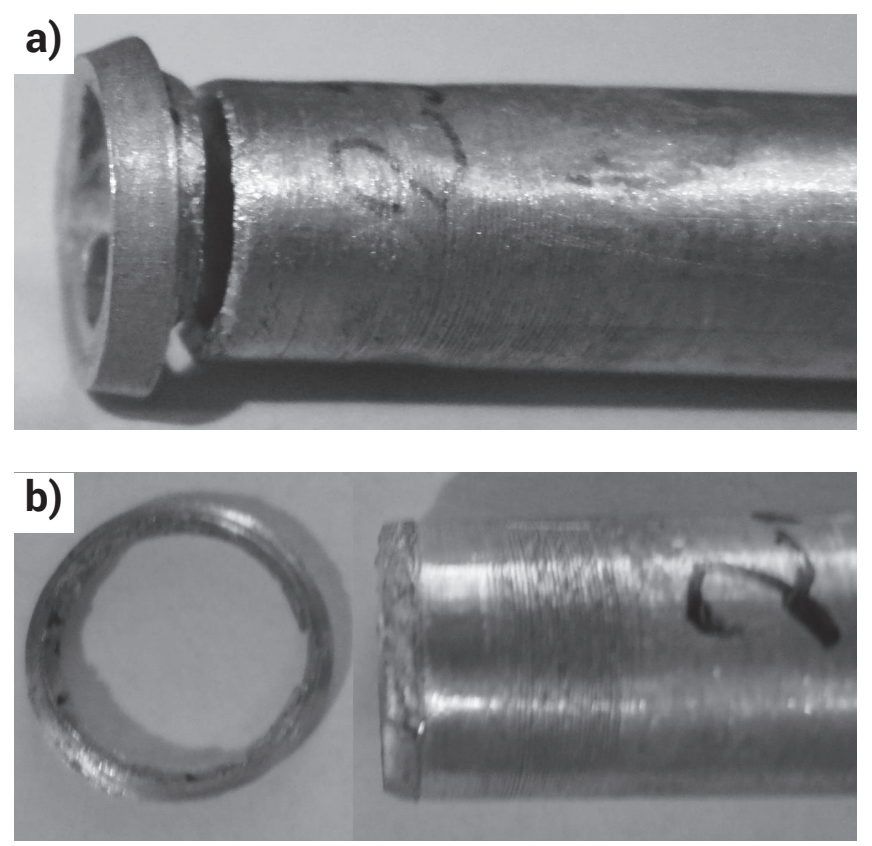

Rys. 8. Przykłady próbek po próbie ścinania: a) próbka z zakładką o długości $2 \mathrm{~mm}$, b) próbka z zakładką o długości 0,9 $\mathrm{mm}$

Fig. 8. Example of the samples after the test shear. a) sample with an overlap of $2 \mathrm{~mm}$, b) sample with an overlap of $0.9 \mathrm{~mm}$ teriale rodzimym (rys. 8a), zdecydowano się na zmniejszenie długości zakładki do 0,9 $\div 1 \mathrm{~mm}$.

Na rysunku 8a przedstawiono próbkę z zakładką $2 \mathrm{~mm}$, a na rysunku $8 \mathrm{~b} 0,9 \mathrm{~mm}$ po badaniach wytrzymałości na ścinanie.

Zestawione na rysunku 9 wyniki pomiarów stanowią średnią arytmetyczną wytrzymałości na ścinanie trzech złączy aluminiowych, dla każdego rodzaju użytego spoiwa.

Analizując przedstawione na rysunku 9 wartości wytrzymałości połączeń aluminiowych wykonanych lutami na osnowie cynku można stwierdzić, że rodzaj użytego spoiwa ma niewielki wpływ na wytrzymałość na ścinanie złączy. Najlepszymi właściwościami wytrzymałościowymi cechowały się połączenia wykonane lutami ze stopu ZnAl2.

\section{Wytrzymałość złączy na ścinanie Rt [MPa]}

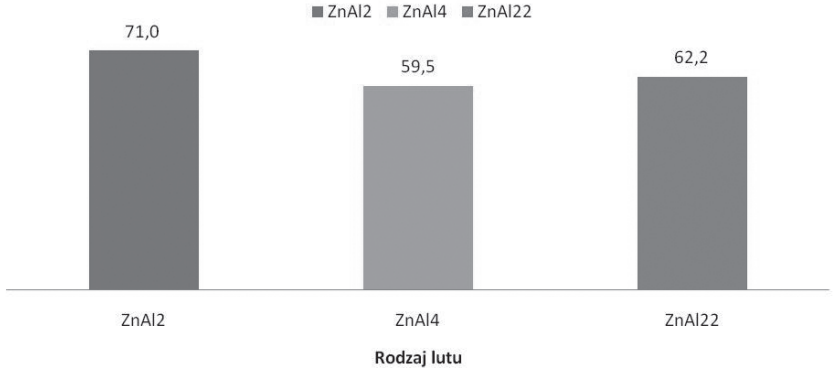

Rys. 9. Wytrzymałość na ścinanie złączy ze stopu EN AW - 6063, w zależności od rodzaju użytego spoiwa

Fig. 9. The shear strength of joints of the alloy EN AW - 6063 due to the type of solder used

\section{Podsumowanie}

Analizując wyniki badań złączy wykonanych przy użyciu różnych spoiw, a także zmienne warianty zastosowania topnika, sformułowano następujące wnioski dotyczące ich wpływu na jakość połączeń aluminiowych uzyskanych przy zastosowaniu metody płomieniowej i indukcyjnej:

- Porównując badane złącza lutowane płomieniowo i indukcyjnie, stwierdzono lepszą estetykę i mniejszą ilość niezgodności lutowniczych w złączach lutowanych indukcyjnie.

- Połączenia kielichowe rurek ze stopu aluminium EN AW-6063 cechowały się największą wytrzymałością na ścinanie oraz najmniejszą nieciągłością lutowiny, wówczas, gdy wykonano je lutami w formie drutu z rdzeniem topnikowym. Maksymalną wytrzymałość na ścinanie wynoszącą 72,2 MPa uzyskana dla połączenia wykonanego spoiwem ZnAl2 z topnikiem znajdującym się w rdzeniu lutu.

- Luty na osnowie cynku, zastosowane do lutowania aluminium, pozwalają na wykonanie złączy o powtarzalnej jakości i średniej wytrzymałości wynoszącej $65 \mathrm{MPa}$.

- Rodzaj użytego spoiwa ze stopu cynku i aluminium w niewielkim stopniu wpływa na wytrzymałość złączy na ścinanie Rt. Maksymalna jej różnica, dla tego samego spoiwa, wynosiła 5,6 MPa.

- Badania wykazały, że przy zakładce o długości $2 \mathrm{~mm}$ wytrzymałość złącza lutowanego była większa niż materiału rurki ze stopu aluminium EN AW-6063 w strefie wpływu ciepła.

\section{Literatura}

[1] Dobrzański L.A.: Metalowe materiały inżynierskie, Wydawnictwa Naukowo-Techniczne WNT 2004.

[2] Ambroziak A., Lange A., Derlukiewicz W., Mosińska S.: Lutowanie twarde aluminium i jego stopów, Przegląd Spawalnictwa 2/2009.

[3] Derlukiewicz W., Bartnik Z.: Lutowanie aluminium i jego stopów w kąpielach solnych, Przegląd Spawalnictwa 9/2007.

[4] Nowacki J., Chudziński M., Zmitrowicz P.: Lutowanie w budowie maszyn, WNT, Warszawa 2007

[5] Mirski Z., Granat K., Drzeniek H.: Luty proszkowe do lutowania twardego aluminium i jego stopów, Biuletyn Instytutu Spawalnictwa, Nr 5/2008.
[6] Winiowski A.: Lutowanie twarde aluminium i jego stopów - nowe trendy technologiczne, Biuletyn Instytutu Spawalnictwa, Nr 6/2000, str. 44.

[7] Mirski Z., Granat K., Drzeniek H.: Luty proszkowe do lutowania twardego aluminium i jego stopów, Biuletyn Instytutu Spawalnictwa, Nr 5/2008, str. 100.

[8] www.lut-spaw.com.pl, Katalog lutów i topników

[9] Mirski Z., Granat K., Drzeniek H., Piwowarczyk T., Wojdat T.: Lutowanie miękkie aluminium z miedzią, Przegląd Spawalnictwa 11/2009.

[10] Specyfikacja techniczna lutu S-Zn98Al2 pobrana ze strony: www.harrisproductsgroup.com/consumables/msds.asp, 14.06.2010. 